ББК 63.4

\author{
Организация конференциии и издание материалов проведень \\ при финансовой поддержке Российского фонда фундаментальных исследований, \\ проект № 19-09-20008
}

Утверждено к печати Ученым советом ИИМК РАН

Редакционная коллегия тома I: В. А. Алёкшин, Л. Б. Кирчо (отв. редакторы),

В. П. Никоноров, В. Я. Стёганцева; В. В. Терёхина

Рецензенты: д. и. н. Л. Б. Вишняцкий, д. и. н. А. А. Выборнов

Программный комитет конференции: академик РАН, д. и. н., проф. М. Б. Пиотровский

(Государственный Эрмитаж, почетный председатель); д. и. н. В. А. Лапшин (ИИМК РАН, председатель); д. и. н. А. В. Головнёв (МАЭ РАН, сопредседатель); д. и. н. В. А. Дергачёв (Высшая антропологическая школа, Молдова, сопредседатель); д. и. н. И. Ф. Попова (ИВР РАН, сопредседатель); академик АН Республики Узбекистан, д. и. н., проф. Э. В. Ртвеладзе (сопредседатель); к. и. н. А. В. Поляков (ИИМК РАН, зам. председателя); к. и. н. В. А. Алёкшин (ИИМК РАН, зам. председателя); д. и. н. Ю. Е. Берёзкин (МАЭ РАН); Dr., Prof. Н. Бороффка (Германский археологический институт, Германия); В. С. Бочкарёв (ИИМК РАН); Dr. Э. Кайзер (Свободный университет Берлина, Германия); к. и. н. М. Т. Кашуба (ИИМК РАН); д. и. н. Л. Б. Кирчо (ИИМК РАН); к. и. н. А. В. Кияшко (Южный федеральный университет); к. и. н. П. Ф. Кузнецов (СГСПУ);

к. и. н. Н. М. Малов (СНИГУ); к. и. н. В. П. Никоноров (ИИМК РАН); Ю. Ю. Пиотровский

(Государственный Эрмитаж); д. и. н., проф. Д. Г. Савинов (Институт истории СПбГУ);

к. и. н. В. Н. Седых (Институт истории СПбГУ); к. и. н. Н. Н. Скакун (ИИМК РАН);

к. и. н. Н. Ф. Соловьёва (ИИМК РАН); к. и. н. А. И. Торгоев (Государственный Эрмитаж); к. и. н. Е. А. Черлёнок (Институт истории СПбГУ)

Организационный комитет конференции: к. и. н. А. В. Поляков (ИИМК РАН, председатель);

к. и. н. В. А. Алёкшин (ИИМК РАН, зам. председателя); В. С. Бочкарёв (ИИМК РАН); ); к. и. н. М. Т. Кашуба (ИИМК РАН); д. и. н. Л. Б. Кирчо (ИИМК РАН);

А. И. Климушина (ИИМК РАН, отв. секретарь); к. и. н. В. П. Никоноров (ИИМК РАН); Ю. Ю. Пиотровский (Государственный Эрмитаж); В. Я. Стёганцева (ИИМК РАН); В. В. Терёхина

(ИИМК РАН, МАЭ РАН, отв. секретарь); к. и. н. Е. С. Ткач (ИИМК РАН); И. Ж. Тутаева (Государственный Эрмитаж); к. и. н. Е. А. Черлёнок (Институт истории СПбГУ)

Древности Восточной Европы, Центральной Азии и Южной Сибири в контексте связей и взаимодействий в евразийском культурном пространстве (новые данные и концепции): Материалы Международной конференции, 18-22 ноября 2019 г., Санкт-Петербург. Т. I. Древняя Центральная Азия в контексте евразийского культурного пространства (новые данные и концепции). К 90-летию со дня рождения патриарха евразийской археологии Вадима Михайловича Массона. - СПб.: ИИМК РАН, Невская Типография, 2019. — 291 с.

ISBN 978-5-907053-34-2

DOI 10.31600/978-5-907053-34-2 


\title{
AGRICULTURE IN THE ANCIENT GONUR OASIS
}

\section{Liliya V. Sataeva}

Bashkir State Agrarian University, Ufa, Russia

Keywords: agriculture, Ancient Margiana, Gonur Depe, Bronze Age.

Gonur-Depe is the large and well-known center of Ancient Margiana (2300-1600 BC). The archaeobotanical analysis has shown that the Gonur population cultivated membranous and bare grain barley, soft and globular wheat, millet; of the legumes - lentils, chickpeas and peas (small-seeded form); of the orchards - apple, cherry-plum, plum, grapes; of the watermelons - melon; all of these demonstrate a diversity of the plants grown.

The agriculture was based on the estuary and irrigation watering. The population used hoes for cultivating the land, sickles for harvesting and processing the crops, as well as specially constructed pits and vessels for storing the grain. Grain seeds were widely used in rituals of the ancient population of Gonur Depe. This testifies to a high level of the development of agriculture in ancient Margiana, which made it possible to provide the population of the city center with agricultural products in the conditions of progressive climate aridization.

\section{EVIDENCE FOR THE INTERACTION SPHERE OF THE GREAT KHORASAN CIVILIZATION DURING THE BRONZE AGE IN NORTHERN AND EASTERN IRAN}

\author{
David M. P. Meier ${ }^{*}$, Ali A. Vahdati** \\ ${ }^{\star}$ University of Tehran, Tehran, Iran; ${ }^{* *}$ Iran Cultural Heritage, Handcrafts and Tourism \\ Organization, Bojnurd, Iran
}

DOI: 10.31600/978-5-907053-34-2-63-64

Keywords: Bronze Age, eastern Iran, Bactria-Margiana archaeological complex (BMAC), Oxus civilization, Great Khorasan civilization (GKC), Chalow, Razeh, Gavand.

The distribution of the objects belongs to the so-called BMAC or the Oxus Civilization have been limited to the area of southern Central Asia with a few exceptions of usually prestige objects which were found outside of this area in Iran, Afghanistan and Pakistan. Recent data and material gathered through archaeological surveys and excavations as well as chance finds, and groups of confiscated objects driving mainly from illegal excavations in northeastern Iran that eventually housed in the local museum collections of the Mofakham Museum in Bojnurd and the Akbariyeh Museum in Birjand in the Northern and Southern province of Khorasan in Iran. These discoveries are contributing to re-define the boundaries of this archaeological cultural complex which now seems to be distributed in a much wider area than formerly perceived, encompassing almost the whole territory of the historical region of Greater Khorasan.

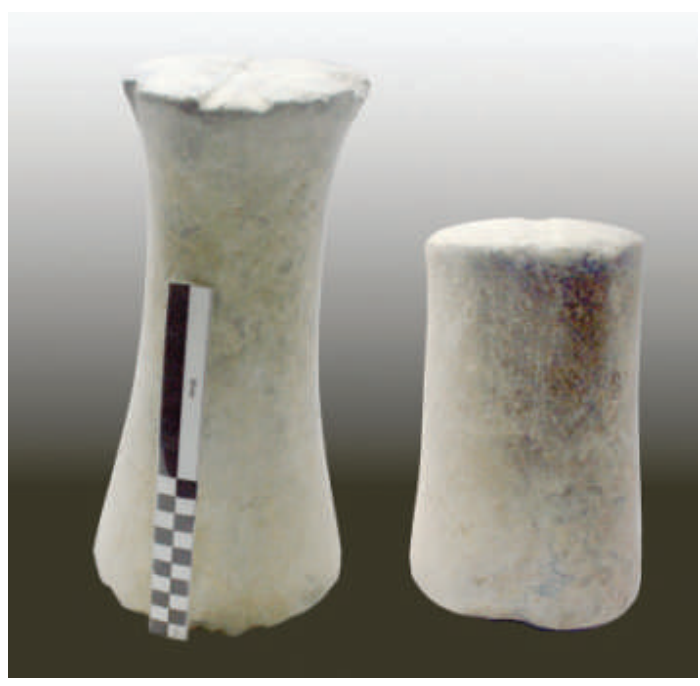

Fig. 1. Stone "columns" from the museums in province of Khorasan, Iran 


\title{
СВИДЕТЕЛЬСТВО О СФЕРЕ ВЗАИМОДЕЙСТВИЙ ВЕЛИКОЙ ХОРАСАНСКОЙ ЦИВИЛИЗАЦИИ В ЭПОХУ БРОНЗЫ В СЕВЕРНОМ И ВОСТОЧНОМ ИРАНЕ
}

\author{
Д. М. П. Майер ${ }^{\star}$ А. А. Вахдати ${ }^{\star *}$ \\ * Тегеранский университет, Тегеран, Иран; ${ }^{* *}$ Организация иранского культурного наследия \\ и туризма, Боджнурд, Иран
}

Ключевые слова: бронзовый век, Восточный Иран, бактрийско-маргианский археологический комплекс (БМАК), Великая Хорасанская изивилизаиия, иивилизация Окса, Разех, Гаванд.

Распределение объектов, относящихся к так называемому бактрийско-маргианскому археологическому комплексу (ВМАК) или цивилизации Окса, ограничено территорией южной части Центральной Азии, исключая ряд престижных объектов, которые были обнаружены за пределами этой территории - в Иране, Афганистане и Пакистане. Новые данные и материалы, собранные в ходе археологических исследований, а также случайные находки и группы предметов, конфискованных из незаконных раскопок в Северо-Восточном Иране и в конечном итоге размещенных в коллекциях Музея Мофахамам в Боджнурде и Музея Акбарие в Бирджанде (провинция Хорасан), вносят большой вклад в переопределение границ этого археологического культурного комплекса, который, как кажется теперь, занимал гораздо более обширные области, чем предполагалось ранее, и охватывал почти всю территорию исторического региона, известного как Великий Хорасан.

\section{IRRIGATING THE DESERT: APPROACHES TO PALEOCHANNEL RECONSTRUCTION IN THE MURGHAB (TURKMENISTAN) DURING THE BRONZE AGE}

\author{
Roberto Arciero \\ Leiden University, Leiden, the Netherlands \\ DOI: 10.31600/978-5-907053-34-2-64-66
}

Keywords: Central Asia, archaeology, Turkmenistan, geoarchaeology, Murghab, Bronze Age.

It is remarkable that many of the earliest complex societies developed in the large river basins situated in desert landscapes. In the past decades, the water management systems of regions such as Egypt and Mesopotamia have been well investigated. However, although scholars have long argued for the importance of the water resource of the Bactria-Margiana archaeological complex (BMAC) in the Murghab inner delta in Turkmenistan, some critical aspects remain poorly investigated when it comes to micro-scale perspective (Lisitsina 1969; Lamber Karlovsky 2013; Cerasetti 2012). The excavations in the region by different international teams in the last two decades - and by mainly Soviet archaeologists in the last century - have uncovered magnificent citadels and impressive material culture (Hiebert 1994; Sarianidi 2009). Certainly, the ancient river network played a key role in the settlement patterns and social complexity of the BMAC. Although largely criticized today, Wittfogel's famous theory about early hydraulic societies still provokes questions about the relationship to water management and power. Even considering that the water availability during the Bronze Age in the Murghab could have been much greater than the present day, the water management and distribution among the settlements represent crucial aspects in the current research agenda. Water distribution necessitates some sort of coordination among citadels and villages that - as pointed out by T. Wilkinson does not always require a centralized power (Wilkinson et al. 2012). Nevertheless, differences in water delivery could lead to water inequality and thus to conflicts among communities. Indeed, 